\title{
Worship in a post-lockdown context: A ritual-liturgical perspective
}

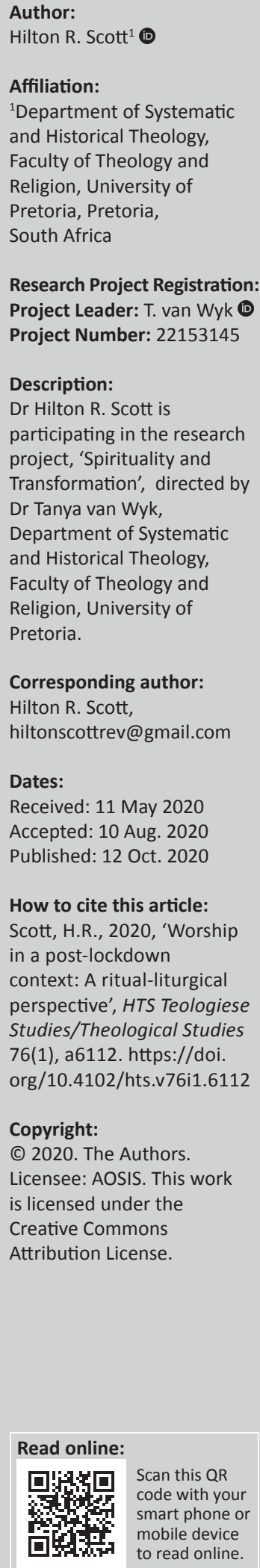

In this unprecedented time, there are many questions and plenty of speculation surrounding what life will be like after the South African nationwide lockdown. There is concern over the effects that the lockdown will have on worship services when churches are in a position to open their doors to the public once more. As a result of recognising the lockdown as a liminal phase, perspectives are shared when considering how the church will gather again in a post-lockdown context and therefore a post-liminal phase. One prevailing perspective in considering this post-liminal phase involves koinonia and how an undiscriminating virus can remind those to further practise inclusivity and ubuntu, by embracing sameness and difference when 'being church'. In contrast, another important perspective focuses on ritualising certain measures in the worship service to prevent the spread of coronavirus disease 2019 (COVID-19), when gathering in church buildings is permissible in a postlockdown context. This is concluded by echoing the spirit of ubuntu, namely, 'I am because we are', in 'being church' during and after the crisis of the COVID-19 global pandemic.

Contribution: From the perspective of Liturgical and Ritual Studies, this article aims to contribute to the Theological perspectives of COVID-19.

Keywords: COVID-19; Nationwide Lockdown; Liminality; Liturgy; Ritual; Inclusivity; Ubuntu; Being church; Transformation.

\section{Introduction}

In all walks of life, there are an unlimited number of questions that could be asked when considering life after the nationwide lockdown ordered by President Cyril Ramaphosa to begin on 27 March 2020 (cf. South African Government 2020(2)). This was ordered in response to the virus known as 'severe acute respiratory syndrome coronavirus 2', or SARS-CoV-2, which causes the disease commonly known as coronavirus disease 2019 (COVID-19) (cf. COVID-19 South African Online Portal 2020). However, church buildings have been without people for worship because the president declared a national state of disaster on the evening of 15 March 2020 (cf. South African Government 2020(1)), by prohibiting gatherings of more than 100 people and encouraging people to limit contact with one another. This quickly prompted churches across the country to provide online sustenance, many of which made use of social media channels to nourish those who were prohibited to sit in their usual chairs and pews. When addressing the nation from the Union Buildings on 23 April 2020 (cf. South African Government 2020), President Ramaphosa said:

We have been forced to adapt to a new way of living, in a short space of time. As we enter the fifth week of an unprecedented nation-wide lockdown - and as we look to the future - we should remember why we are here. (n.p.)

Whilst ordained ministers, preachers and worshippers alike have been working from home, a lockdown is a temporary measure, and a time will come when people are able to return to churches for worship. This means considering a new way of worship - of coming together and 'being

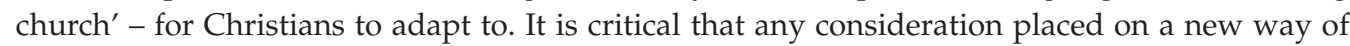
worship includes practising social distance and sound hygiene. These, along with other considerations, beg the question how will the church gather again?

From the abundance of information provided by the South African government as well as the World Health Organization regarding COVID-19 (cf. 5.), what should be well known is that life cannot return to what it was before the pandemic began, purely to limit the spread of the

Note: Special Collection entitled COVID-19 from a Theological Perspective, sub-edited by Jerry Pillay (UP). 
virus (cf. Eyewitness News 2020; South African Government 2020(4); Tralac 2020; Williams 2020). The question of how the church should go about gathering again has two important parts to it: on the one hand, there is the mere concern of churches filling with people in a post-lockdown context and what that community will look like, and on the other hand, there is the concern over further containing COVID-19 and how churches will have to adapt certain rituals and practices to prevent its spread.

When visualising people gathering in churches again after lockdown restrictions have been lifted, a notion of the reconvening of the body of Christ comes to mind. Unlike other memberships, like a gym or country club for example, being an inclusive member of the body of Christ should mean being part of an inseparable worship community (cf. Bouteneff 2009:355; Scott 2018:193; Thiselton 2015:314). During the national state of disaster and the nationwide lockdown, the body of Christ was dispersed from the church to the households of its members, who were separated - but only physically. Therefore, as these members are inseparable and still part of the body of Christ, albeit from distance, the term 'reconvening' is used to describe that which cannot be separated coming together again - physically. However, reconvening cannot mean continuing with worship as it was before COVID-19, at least from a ritual-liturgical perspective.

From a ritual-liturgical perspective, the reconvening of the body of Christ is seen as a post-liminal phase, the outcome of a momentous metamorphosis (or transformation) from which life and being church will never again be the same (cf. Grimes 2000:6; Scott \& Wepener 2017). Before discussing a new post-liminal way of worship, it is important to describe the national lockdown as the 'phase of liminality', which is betwixt and between the norms of a pre-pandemic church and post-lockdown church.

\section{The liminality of lockdown}

The term 'liminality' was traditionally used to describe a threshold, originating from the Latin word limen [threshold] (cf. Barnard 2010:69 \& 78 as examples; Cilliers 2010:344). The phrase that is perhaps most synonymous with 'liminality' is 'betwixt and between' (cf. Turner 1995:107; Van Gennep 1960), referring to a period of transition 'from one life cycle to the other' (Cilliers 2010:344, cf. Van Gennep 1909). In this case, the liminal phase is the national lockdown and all the associated regulations, a period of plenty transition as the general population has been forced into, as Ramaphosa said, a new way of living that needs quick adaptation. With the lockdown came many prescribed guidelines from the government, forcing the vast majority to rethink the way they do everyday life (cf. Department of Co-operative Governance and Traditional Affairs 2020). Of most concern to the church are probably the restrictions that have been placed on the number of people that can gather publicly, the request to minimise the amount of person-toperson contact and the urgent need to constantly clean and sterilise hard surfaces and items that are in contact with more than one person.

A liminal phase is one of ambiguity or a stage between two situations or statuses (Cilliers 2010:344, also cf. Barnard 2010; Turner 1995; Van Gennep 1960; Wepener 2014:27-30). In essence, liminality is a phase in between a certain structure and a new structure, meaning it is essentially an anti-structure in which a transition happens. Liminality begins at the end of one stage and ultimately concludes with the beginning of a new stage or life cycle. In this case, a liminal phase began in South Africa on 27 March 2020, when life as South Africans knew it irrevocably changed. Before the beginning of the national lockdown there was structure, or a status quo, a preliminal phase in which COVID-19 was not a threat to society or the worshipping community, when worshipping in a church and being the body of Christ in the same building was the norm, when being in proximity to another person was encouraged and distancing was discouraged.

The national lockdown is a period of transition from the prepandemic status quo to what is colloquially being referred to as a 'new normal'1 or, as Cilliers (2010:344) wrote in regard to a post-liminal phase, a 'new status quo'. The importance of first describing the lockdown as a liminal phase lies in the details of what can transpire during the period of transition. In addition, by defining the lockdown as a liminal phase, there is an acknowledgement that the previous status quo is no more and that a new life cycle will begin after the lockdown is lifted. The lockdown, and therefore liminality, brings about the sense 'of being in no man's land, where the landscape appears completely different' and importantly where 'there is no [discernible] road map, and where the journeyer is jolted out of normalcy' (Franks \& Meteyard 2007:216). As mentioned in the 'Introduction', speculation surrounding life after the lockdown is rife; there is no definite blueprint or design for how life will commence, let alone how the church will gather again.

An important attribute of a liminal phase is a communitas, a transitional space marked by human interrelatedness taking alternative forms (cf. Barnard 2010:70-71; Wepener 2014:27-30). The communitas, or new community, is created at the termination of the status quo, where transition begins and ultimately leads to a new status quo. This liminal phase and the communitas, as antistructure that exists within, cannot be maintained indefinitely, 'sometimes acquires a certain autonomy' (Van Gennep 1960:192) and is 'to a degree unstable' (Barnard 2010:70). President Ramaphosa and his advisors have explained that the lockdown cannot continue indefinitely, whilst instability is most noticeable in the unrest in communities and the deployment of the South African National Defence Force (SANDF) (cf. Gerber 2020; South African Government 2020(5)). The autonomous quality of the lockdown is noticeable in the difference between the status 1.As referred to in the introduction (cf. Eyewitness News 2020; South African Government 2020(4); Tralac 2020; Williams 2020). 
quo that existed with people having an abundance of freedoms including of movement, of choice, of purchase and sale, of consumption, of visitation and so on.

According to Cilliers (2010:344), liminality 'represents a highly creative phase or space, where the combinations of new forms and relations is possible'. The borders of liminality are porous and open to all sides. Therefore, the South African nationwide lockdown is a creative space with plenty of reflection and revelation, filled with the potential to be fruitful or destructive, a phase of fullness and emptiness (cf. Barnard 2010; Cilliers 2010; Wepener 2015). A phase of liminality presupposes, within the anti-structure, a different level of freedom for the communitas to reflect on the past, to envision the future, to rethink and re-imagine ideas and practices and to alternatively interpret reality (cf. Lee 2001:98). The liminal phase and the period of the South African nationwide lockdown can be summarised by the following quote from Turner (1969):

Liminal entities are neither here nor there; they are betwixt and between the positions assigned and arrayed by law, custom, convention, and ceremonial. As such, their ambiguous and indeterminate attributes are expressed by a rich variety of symbols in the many societies that ritualise social and cultural transition. (p. 95)

Turner (1969:106-107) also lists the characteristics of liminality by means of binary opposites, some of which can be applied to the lockdown situation the world is facing now. These binary opposites characterise the lockdown as liminal: '[t]otality/partiality', ' $h$ h $]$ omogeneity/heterogeneity', '[u]nselfishness/selfishness', '[c]ommunitas/structure', '[s]ilence/speech' and '[s]implicity/complexity'. From the perspective of ritual studies, the liminal phase forms part of a tripartite structure (cf. Janssen 2000:31; Turner 1969, 1995), otherwise referred to as a 'threefold pattern' (cf. Barnard, Cilliers \& Wepener 2014:67), or 'threefold scheme' (cf. Grimes 2000:104), that includes a pre-liminal phase and a postliminal phase, of which rites are constructed. As mentioned above, the pre-liminal phase is the status quo, norm or 'everyday life' that existed in South Africa until the nationwide lockdown began. In between what was and what will be - a new status quo - is a period of transition. Turner refers to the first two parts as separation and liminality. The post-liminal phase, as referred to by Turner, is one of reintegration (cf. Wepener 2014:3). The question being asked throughout is how will the church gather again? This, as seen from a liturgical-ritual perspective, can also be asked as how will worshippers reintegrate into being church? With an understanding of the nationwide lockdown as a liminal phase, perspectives of a post-liminal - post-lockdown phase can be described in turns of koinonia.

\section{Koinonia after the lockdown}

From the subject field of Practical Theology, the normative task of practical theological interpretation involves asking the question 'what ought to be going on?' (cf. Osmer 2008:4).
However, these are unprecedented times, liminal times at that, meaning that there is no road map or blueprint. Moreover, liminality infers a time of reflection and/or revelation, as described in the above. Thus, suggestions can be made as to what worship in a post-lockdown context could look like by reflecting on descriptions of koinonia and all the changes to life that have happened during periods of liminality. These suggestions, from the perspective of Liturgical Studies and Systematic Theological Ecclesiology, describe the status quo before the lockdown began, combined with the new way of life that South Africans have had to adapt to, thereby developing a vision of a new status quo. Such interpretation will begin with descriptions of koinonia, so that it can be better understood as what it could be after the lockdown - when the church can gather again.

The term koinonia - referring to communion or fellowship comprises a vertical aspect and a horizontal aspect; the former refers to the relationship between God and the believer, whilst the latter refers to the relationship(s) between believers (cf. Zizioulas \& McPartlan 2007:4-12, 189 \& 245, also McGrath 2007:407; Scott 2018:173). In considering 'being church', the concern is over the so-called horizontal component of koinonia in a post-lockdown context, namely, the relationship(s) between believers or, from an African perspective, ubuntu. These terms are comparable, along with the Pauline concept of the body of Christ, as each describes the coming together of people in - what Thiselton (2007:313) calls - 'common participation' (cf. Scott 2018:173-176). Whether identifying with the notion of ubuntu, the body of Christ or simply koinonia as communion, fellowship or community, the overarching idea is the gathering of individuals to form a collective. The concept of ubuntu is often explained as 'I am because we are', , denoting that the individual exists because of - and in relation to the collective. Likewise, the collective exists because of the coming together of individuals, meaning that the we exists because of several Is together.

In a normative sense, the horizontal component of koinonia describes a community of believers that have relationships and relatedness (Strachan 2015:1) with one another in fellowship and worship. All such individuals in common participation are, in simple terms, 'being church' and therefore exist together as a collective, as a church or as a body of Christ. When asking the question how will the church gather again, what is also being asked is how ought the church to gather again? As with other places where people gather, such as shops and offices, strict measures should be put in place to prevent the spread of COVID-19 at church. Therefore, questions arise, such as how does social distancing work during fellowship? Before answering any such questions, what ought to be understood is that, in a normative sense, common participation is an important concept, and the collective exists because individuals came together. With the deadly threat that COVID-19 poses to the population worldwide in mind, individuals need to participate 2.1 I am, because we are; and since we are, therefore I am' (Mbiti 1969:108). 
differently from before to protect the collective. As a result, what believers knew as the status quo of being church ought to be transformed for the safety and protection of the body of Christ. This epitomises the notion of ubuntu, in 'reflective nostalgia' (Müller 2015:2), as individuals act as a collective to protect the we and in turn the $I$, meaning that in this context ubuntu could be: 'I am safe because we are safe', 'I am protected because we are protected' or 'I am healthy because we are healthy'. Such a normative approach can be taken because fellowship is not simple a social exchange (Scott 2018:175) like that between a customer and a cashier; instead, it is 'common participation as one who holds a joint share in the body of Christ' (Thiselton 2007:313).

During the nationwide lockdown period, the notion of ubuntu can be highlighted by acknowledging the communitas and its united role of playing its part (cf. 4) by accepting the regulations of the lockdown. Eliastam (2015:1) argues that the notion of ubuntu has been eroded 'to the extent that it currently seems unable to play a meaningful role in nationbuilding'. In contrast, Müller (2015:2) states that knowledge of ubuntu is based on perceptions: 'Our ideas about how our current societies operate are in the same sense based on perceptions'. The perception here is that the liminal state of society during the lockdown both exhibits and creates a space for the notion of ubuntu as an ideal for the future of nation building. However, it is important to not only highlight the positives of ubuntu in this context but also entertain the paradoxes (cf. Müller 2015:3).

An example of the paradoxical ubuntu story within the lockdown context is, on the one hand, the positive perspective of a nation united in fighting the spread of a virus - the coming together of all people from all races and cultures. On the other hand, there is the negative perspective of a clear divide between the lived lockdown experiences of the wealthy and impoverished, or the salary-based work-from-home employee and the self-employed small business owner unable to source an income, for example. The overarching perspective of ubuntu here is comparable to goodness or good neighbourliness. Müller (2015:3) writes that ' $[g]$ oodness and ubuntu are similar and related concepts. It is all about relations and community'. Whether using the concept of goodness or ubuntu, the notion is an ideal or 'promises to become' (Müller 2015:3); hence the perception that the nationwide lockdown creates a space for ubuntu in a nation collectively fighting the spread of COVID-19.

In no uncertain terms should the church oblige with the guidelines and protocol that are advised by government in order to minimise the spread of COVID-19 throughout church communities, as well as the associated communities and wider society. Likewise, individual members, holding a joint share and therefore responsibility, of the body of Christ should abide by the same regulations for the good of the collective. On the one hand, COVID-19 ought to be seen as what it is: a communicable disease that is responsible for the deaths of thousands of people worldwide. However, on the other hand, what ought to be considered is the effect that this virus has had on society and what the church, as a community, can learn from it. A statement made by the United Nations Network on Migration (cf. Unicef 2020) includes the phrase: 'COVID-19 does not discriminate, and nor should our response, if it is to succeed'. Similarly, Adriaan Roets (2020) wrote a popular article titled 'Race, gender and social status mean nothing when affected with Covid-19...'. The premise in both examples is that the virus named COVID-19 does not discriminate; it does not see differences between humans, such as age, race, gender, culture or economic status.

With the lockdown, and the easing of restrictions thereafter, being seen as a liminal phase, the idea of a virus that does not discriminate provides a space for the church to consider the so-called new status quo in post-liminality. The idea - which is somewhat utopian - is that a virus that does not (or did not) discriminate could aid in transforming the church, and as a result the wider society, into a collective that acknowledges a human for being human instead of different.

\section{The COVID-19 pandemic as encouragement for a further inclusive church}

The virus known as SARS-CoV-2, which causes the disease commonly known as COVID-19, is spread from person to person and importantly does not discriminate (cf. 5, COVID-19 South African Online Portal 2020(1)). One need only follow the statistics published by the World Health Organization, national governments, health departments and the media alike to realise that this disease can both infect and kill any human (cf. COVID-19 South African Online Portal 2020(3); World Health Organisation 2020). Stating that the virus does not discriminate simply means that it recognises only a human, nothing more and nothing less. In the context of a country such as South Africa where there are clear divides in society, not necessarily racial ones - however important economically - there is an important lesson that ought to be learnt: all South Africans are only human. South Africans are black; they are white; they are wealthy; they are impoverished; they are men, women and children; they are heterosexual, homosexual and asexual; they are young and old; they have chronic conditions; they have human immunodeficiency virus and acquired immune deficiency syndrome; they have mental illnesses; and they are in good health but - with COVID-19 serving as an important reminder - they are ultimately human. The coronavirus (SARS-CoV-2) that came to the fore in 2019 does not recognise the divides in South African society, which has resulted in a nationwide lockdown.

The national lockdown ordered by President Cyril Ramaphosa has provided South Africans, including the church, with an important liminal space where transformation will occur, culminating with a new status quo. This new community or communitas could give rise to a South African church that 
truly practises the inclusive notion of ubuntu - a utopian ideal (cf. Scott 2018:175). As South Africans continue to strive for a society devoid of discrimination and the associated pain and suffering, the undiscriminating nature of COVID-19 can further assist South Africans to acknowledge humanity rather than difference or otherness. President Ramaphosa has called on South Africans, 'all of us, one and all, to play our part', whilst reiterating that 'we are a nation at one' (cf. South African Government 2020(2)). This call was made at the beginning of the lockdown and can therefore be identified as the formation of a communitas - a new community as one. The potential that comes with this communitas is a new status quo that is fully human and therefore able to accept difference and otherness as well as navigate such relationships without discriminating (cf. Ackermann 1998; Scott \& Wepener 2020:5-6).

Like COVID-19, which has caused a global pandemic, the South African national lockdown does not discriminate and requires all South Africans to play their part. The aim of the role that all South Africans should play is to give other South Africans, who otherwise would have been infected by the virus, the opportunity to proclaim the essence of ubuntu: 'I am because we are; and since we are, therefore I am' (Mbiti 1969:108). When the pandemic has passed and, in postliminality, there is a new status quo, South Africans should hold on to the heterotopia that was the lockdown, where the nation stood as one in an other space. This other space - or heterotopia - is one where the ideals of, in this case, ubuntu become 'visible and tangible, real and traceable' (Van Wyk 2014:4). In other words, the liminal phase of the nationwide lockdown is here being referred to as a 'heterotopia' - a space of contrast (cf. Foucault \& Miskowiec 1986:24; Post 2010:100). Foucault describes heterotopias as having the following traits: either creating 'a space of illusion that exposes every real space, all the sites inside of which human life is partitioned, as still more illusory' or a space 'that is other, another real space, as perfect, as meticulous, as well arranged as ours is messy, ill constructed and jumbled' (Foucault \& Miskowiec 1986:27). Compared to human life as it was before, the lockdown exhibits the trait of being another real space where the ideal of ubuntu is visible and real.

Therefore, looking at how the church will gather again in a post-lockdown context, one worthwhile outcome will be the church gathering inclusive of all humans in common participation. This outcome could arise from the porous borders of liminality that provide South Africans with an (other) space where there is reflection on an unjust past that divided people based on differences and the possibility for revelation in becoming 'fully'3 inclusive (cf. Ackermann 1998; Cilliers 2010; Scott \& Wepener 2020; Van Wyk 2014; Wepener 2015).

South Africans, as a communitas and thereafter a new community, can continue to play their collective role as one nation, as the president called them to do. Likewise, the 3.Borrowing from Ackermann's idea of 'fully human' (cf. 1998). church has been given the opportunity to become a more homogenous space where the heterogeneous aspects of South Africans, or Christians for that matter, is second to their humanness and joint share in the body of Christ (cf. Thiselton 2007:313, 2015:321; Van Wyk 2014:2; Volf 1996:40; Zizioulas 2006:13). Kärkkäinen (2002:96) writes that 'being in communion does not, however, mean downplaying the distinctive personhood of each individual'. The ideal that could be realised in a post-lockdown South Africa is the understanding that each member of the body of Christ is different but inherently human and should be accepted as such. Thus, we should minimise discrimination and the pain it causes whilst being cognisant of the essence of ubuntu, of 'being church' with different humans - 'I am church because

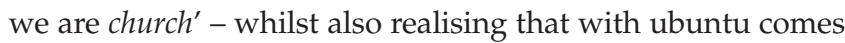
paradox and 'multilayeredness' and that the concept 'will always be a mix of desire, nostalgia, and what is really happening' (Müller 2015:3). Van Wyk (2019:1-2) uses the notion of 'necessary paradoxes' in describing the transformation, in binary terms, of us and them (or us/them) that is being called for in pluralistic human landscapes in South Africa. In this sense, transformation toward the ideal of, or promise of becoming, ubuntu involves a paradox of both/ and when engaging and embracing both sameness and difference, wherein there is a creative tension between 'the connection of identity to being demarcated whilst opening up space and "inviting in"' (Van Wyk 2019:2 \& 5-7). This is one perspective of worship, and an ideal for being church through transformation, in a post-lockdown context in pluralistic South Africa. From a ritual and liturgical perspective, consideration also needs to be given to certain liturgical rites and practices.

\section{Ritualising hygiene and social distancing in the worship service}

In the previous section, a perspective on how the church can gather again was described with a concern over the inclusive and exclusive tension ${ }^{4}$ of koinonia in South Africa and how the lockdown as a liminal phase provides a space for being church more inclusively. Another pressing perspective on how the church will gather again involves considering the guidelines from the South African Department of Health to prevent the spread of COVID-19. After reading a popular article on how religious services could be conducted in Germany (Connolly 2020), it is clear that there ought to be a new status quo in the post-liminal, post-lockdown phase that includes measures to prevent this disease being spread from one person to another. This new status quo can be compared to the process of ritualisation. Ritualisation describes the formation of rituals in the same sense that the drama seen on television or stage began with social drama in everyday life (cf. Grimes 2010:33\&35; Miller-McLemore \& Wiley-Blackwell (Firm) 2014:145; Scott 2018:140). Various concerns along with the available guidelines will be described as themes below.

4.cf. Scott (2018:174-176), also Van wyk (2019:2 \& 9), referring to the creative tension between difference and sameness. 


\section{Singing during the worship service}

One of the concerns that epidemiologists and physicists share is the spread of COVID-19 as a result of singing. According to Lohse (2020:4), there is an urgency to answer many open questions about the fluid physics of singing, speaking and even exhaling - including coughing and sneezing. Connolly (2020), in an article discussing guidelines that are being considered to open places of worship in Germany, writes that:

Communal singing has reportedly proved to be a particular sticking point in the discussions, despite repeated warnings by leading epidemiologists that singing is as dangerous as coughing for spreading the virus. (n.p.)

There is no conclusive evidence; however, a study found that infections from airborne droplets of SARS-CoV-2 is plausible, 'since the virus can remain viable and infectious in aerosols for hours' (cf. Van Doremalen, Bushmaker \& Morris 2020). Such a possibility could lead to there being either reverent, soft singing or none at all.

\section{Hygiene guidelines for entering the church}

The guidelines that have been advised by the South African government to all individuals as preventative measures for spreading COVID-19 are as follows:

- Wash your hands often with soap and water for at least 20 seconds. If soap and water are not available, use an alcohol-based hand sanitiser.

- Avoid touching your eyes, nose and mouth with unwashed hands.

- Avoid close contact with people who are sick.

- Stay at home when you are sick and try and keep a distance from others at home.

- Cover your cough or sneeze with a flexed elbow or a tissue, then throw the tissue in the bin.

- Clean and disinfect frequently touched objects and surfaces. (COVID-19 South African Online Portal 2020)

The church and all who will worship within its walls should not be exempt from these measures. Generally, if a person makes a conscious effort to keep free of contaminants and remain out of the company of others when ill, then diseases such as COVID-19 do not spread as fast. In addition, like shops and businesses, churches should clean and disinfect all surfaces regularly to reduce the chance of infection.

\section{The Eucharist}

An element of liturgy that requires consideration and worthwhile ritualisation is the Eucharist. Coronavirus disease 2019 is known to spread from person to person or through points of contact; as such the Eucharist as a ritual poses a risk. In the guidelines stipulated above, one is advised to avoid touching one's eyes, nose and mouth. Thus, if a person carrying the virus was to sip from a cup whilst partaking in the Eucharist, for example, the next person would - as part of the ritual - sip from the same cup and potentially contract the virus. According to Connolly (2020), religious leaders in Germany have agreed on the prohibition of anything that may contain bodily fluids - for example administering communion from hand to mouth. There should be a clear concern over conducting and partaking in the Eucharist, as certain surfaces, including copper, stainless steel and plastic, are viable environments for SARS-CoV-2 to be infectious for varying durations (cf. Van Doremalen et al. 2020).

\section{Social distancing}

The practice of social distancing is ever prevalent, especially in situations where there are queues of people. The distance varies between $1 \mathrm{~m}, 1.5 \mathrm{~m}$ and $2 \mathrm{~m}$; however, the South African Department of Health (COVID-19 South African Online Portal 2020[2]) advises the following.

The term 'social distancing' basically means that one needs to keep one's distance from others. This includes avoiding public spaces such as malls, the workplace and, of course, social events as well as recreational areas where others usually gather. One needs to avoid handshakes, hugs and other forms of direct contact, as well as keeping a distance of at least $2 \mathrm{~m}$ from others.

By following this advice, the church ought to urge worshippers to refrain from direct contact such as greeting with physical gestures. In addition, worshippers ought to be at least $2 \mathrm{~m}$ apart for the duration of the worship service.

\section{Being church during (and after) crisis}

In his book Caring Worship, Howard Vanderwell (2017:91) writes that in times of 'communitywide' crises the events of such cannot be ignored in worship. As a result, Vanderwell (2017:90-95) describes certain measures that can be put into place to care for the congregation - and the surrounding community. Accordingly, there are four options that those planning the worship service usually have (1) to proceed as normal with the worship service and do nothing related to the crisis, which is risky; (2) to make slight changes by focussing parts of liturgy on the crisis this is done in addition to what has been planned, which remains intact; (3) to make more extensive changes to the liturgy, setting aside a portion of the service that is devoted to the crisis and allows the congregation a space to reflect and express their reactions; and (4) to completely revise the worship service - such circumstances do not often occur, but when they do happen, the church should respond to the time of crisis (Vanderwell 2017:91-92). A tool is also provided to assist those involved with planning worship services to gauge the severity of the crisis and appropriate response:

Level 1 - Only a small number of worshippers are affected. Minor modifications to the liturgy are made. 
Level 2 - The event has potentially a major impact on a larger number, perhaps nearly half of the worshippers. A new and pastorally appropriate worship service is planned.

Level 3 - The event has a profound and long-term impact on nearly all in the worshipping community. The worship leaders give long-term (multiple weeks) attention to the needs of worshippers.

There is little reason to not acknowledge that the COVID-19 global pandemic is at least a level 3 crisis. As a result, the reopening of churches ought to include a response that tends to the needs of all worshippers. The impact of this global pandemic has so far been profound; the term 'global' should be an indication of the magnitude of the impact of COVID-19.

\section{Conclusion}

Along with the abovementioned response should be a new status quo that resembles a more inclusive fellowship by engaging and embracing both sameness and difference, as the notion of ubuntu has become tangible in the context of the lockdown - including its paradoxes and different perspectives (cf. 4. \& Müller 2015:3). The stark contrast is that what could result in a more inclusive church, and society, stems from exclusion in the form of social distancing. This has also resulted in the contrast of communities that have come together (metaphorically), in a profound manner, to be apart (literally). Whilst there is a theme throughout this article of inclusive gatherings when being church, resulting in proximity, there is also a need as a society to practise distance. As a result, there also ought to be stringent measures that limit person-to-person contact and encourage the prevention of spreading COVID-19. As a utopia in a South African church, the unity of all members, the acceptance of all members and preventative measures during common participation in ritual in the midst of a undiscriminating virus all ought to echo the spirit of ubuntu: 'I am because we are'.

\section{Acknowledgements}

The author acknowledges the contribution made by Dr Tanya van Wyk, who shared her insights and expertise during the process of writing this article.

\section{Competing interests}

The author declares that he has no financial or personal relationships that may have inappropriately influenced him in writing this research article.

\section{Author's contribution}

H.R.S. is the sole author of this research article.

\section{Ethical considerations}

This article followed all ethical standards for research without direct contact with human or animal subjects.

\section{Funding information}

This research received no specific grant from any funding agency in the public, commercial or not-for-profit sectors.

\section{Data availability}

Data sharing is not applicable to this article as no new data were created or analysed in this study.

\section{Disclaimer}

The views and opinions expressed in this article are those of the author and do not necessarily reflect the official policy or position of any affiliated agency of the author.

\section{References}

Ackermann, D.M., 1998, 'Becoming fully human: An ethic of relationship in difference and otherness', Journal of Theology of Southern Africa 102, 13-27.

Barnard, M., 2010, 'Flows of worship in the network society: Liminality as heuristic concept in practical theology beyond action theory', In die Skriflig 44(1), 67-84. https://doi.org/10.4102/ids.v44i1.137

Barnard, M., Cilliers, J. \& Wepener, C., 2014, Worship in the network culture: Liturgical Ritual Studies: Fields and methods, concepts and metaphors, Liturgiacondenda 28, Peeters, Leuven.

Bouteneff, P.C., 2009, 'Ecumenical ecclesiology and the language of unity', Journal of Ecumenical Studies 44(3), 352-360.

Cilliers, J., 2010, 'The liminality of liturgy', Scriptura 104(1), 343-351. https://doi. org/10.7833/104-0-175

Connolly, K., 2020, 'Germany to set out rules for religious services including singing ban', The Guardian, viewed 06 May 2020, from https://www.theguardian.com/ world/2020/apr/29/germany-to-set-out-rules-for-religious-services-includingsinging-ban?fbclid=IwAROetx7U-4Uq_VAvEA72y3Kr47m9o4ii-sH8YYtqqBmyrtLs3 singing-ban?
vwhYuVPMcl.

COVID-19 South African Online Portal, 2020(1), 'About COVID-19 (Coronavirus)', Department of Health Republic of South Africa, viewed 05 May 2020, from https:// sacoronavirus.co.za/information-about-the-virus-2/.

COVID-19 South African Online Portal, 2020(2), 'Social distancing explained', Department of Health Republic of South Africa, viewed 06 May 2020, from https:// sacoronavirus.co.za/2020/04/08/social-distancing/.

COVID-19 South African Online Portal, 2020(3), 'COVID-19 corona virus South African resource portal', Department of Health Republic of South Africa, viewed 11 May 2020, from https://sacoronavirus.co.za/.

Department of Co-operative Governance and Traditional Affairs, 2020, 'Disaster management act, 2002: Amendment of regulations issued in terms of Section 27(2)', Government Gazette, 26 March 2020, viewed 07 May 2020, from https:// www.gov.za/sites/default/files/gcis_document/202003/43168reg11067gon419. pdf.

Eliastam, J.L.B., 2015, 'Exploring ubuntu discourse in South Africa: Loss, liminality and hope', Verbum et Ecclesia 36(2), Art. \#1427, 1-8. https://doi.org/10.4102/ve. v36i2. 1427

Eyewitness News, 2020, 'COVID-19 quick insights from 22 April', viewed 07 May 2020, from https://ewn.co.za/2020/04/23/covid-19-quick-insights-from-22-april.

Foucault, M. \& Miskowiec, J., 1986, 'Of other spaces', Diacritics 16(1), 22-27. https:// doi.org/10.2307/464648

Franks, A. \& Meteyard, J., 2007, 'Liminality: The transforming grace of in-between places', The Journal of Pastoral Care and Counseling 61(3), 215-222. https://doi. org/10.1177/154230500706100306

Gerber, J., 2020 "“You're not our clients. We take instructions from the president" SANDF to MPs amid brutality claims', News24, viewed 07 May 2020, from https:// www.news24.com/SouthAfrica/News/military-rattles-sabres-amid-complaintsof-heavy-handedness-20200422.

Grimes, R.L., 2000, Deeply into the bone: Re-inventing rites of passage, University of California Press, Berkeley, CA.

Grimes, R.L., 2010, Beginnings in ritual studies, 3rd edn., Ritual Studies International, Waterloo.

Kärkkäinen, V.M., 2002, An introduction to ecclesiology: Ecumenical, historical \& global perspectives, InterVarsity Press, Downers Grove, IL.

Lee, S.H., 2001, 'Worship on the edge. Liminality and the Korean American context', in B.K. Blount \& L.T. Tisdale (eds.), Making room at the table: An invitation to multicultural worship, pp. 96-107, John Knox Press, Westminster.

Lohse, D., 2020, 'News \& views: The distance rule in times of corona', Physik Journal 19(5), viewed 06 May 2020, from https://arxiv.org/abs/2004.14150.

Mbiti, J.S., 1969, African religions and philosophy, Heinemann Educational Books Ltd, London. 
McGrath, A.E., 2007, Christian theology: An introduction, 4th edn., Blackwell Publishing Ltd, Malden, MA

Miller-McLemore, B.J. \& Wiley-Blackwell (Firm), 2014, The Wiley-Blackwell companion to practical theology, Wiley-Blackwell, Malden, MA.

Müller, J., 2015, “Exploring "nostalgia” and "imagination" for ubuntu-research: A postfoundational perspective', Verbum et Ecclesia 36(2), Art. \#1432, 1-6. https:// doi.org/10.4102/ve.v36i2.1432

Osmer, R.R., 2008, Practical theology: An introduction, Eerdmans, Grand Rapids, MI.

Post, P., 2010, Voorbij het kerkgebouw: De speelruimte van eenander sacral domein, Uitgeverij Abdij van Berne, Heeswijk.

Roets, A., 2020, 'Race, gender and social status mean nothing when affected with Covid-19 - But celebs are using their platform to promote safety, and looking for ways to recover the money they would have made from gigs', The Citizen, viewed 05 May 2020, from https://citizen.co.za/lifestyle/your-life-entertainment-yourlife/entertainment-celebrities/2256249/coronavirus-does-not-discriminate/.

Scott, H.R., 2018, 'Praying, believing and being church: A ritual-liturgical exploration', $\mathrm{PhD}$ thesis, Faculty of Theology, University of Pretoria.

Scott, H.R. \& Wepener, C.J., 2017, 'Healing as transformation and restoration: A ritualliturgical exploration', HTS Theological Studies 73(4), 1-9. https://doi.org/10.4102/ hts.v73i4.4064

Scott, H.R. \& Wepener, C., 2020, 'Ubuntu in the worship service as heterotopia: A liturgical-ecclesiological exploration', In die Skriflig 54(1), a2514. https://doi. org/10.4102/ids.v54i1.2514

South African Government, 2020(1), 'President Cyril Ramaphosa: Measures to combat Coronavirus COVID-19 epidemic', viewed 29 April 2020, from https://www.gov.za/ speeches/statement-president-cyril-ramaphosa-measures-combat-covid-19epidemic-15-mar-2020-0000.

South African Government, 2020(2), 'President Cyril Ramaphosa: South Africa's response to Coronavirus COVID-19 pandemic', viewed 29 April 2020, from https:// www.gov.za/speeches/president-cyril-ramaphosa-escalation-measures-combatcoronavirus-covid-19-pandemic-23-mar.

South African Government, 2020(3), 'President Cyril Ramaphosa: South Africa's response to Coronavirus COVID-19 pandemic', viewed 29 April 2020, from https:// www.gov.za/speeches/president-cyril-ramaphosa-south-africas-responsecoronavirus-covid-19-pandemic-23-apr-2020.

South African Government, 2020(4), 'Premier Alan Winde: Coronavirus COVID-19 Western Cape government approach', viewed 07 May 2020, from https://www. gov.za/speeches/premier-alan-winde-coronavirus-covid-19-western-capegovernment-approach-7-may-2020-0000.

South African Government, 2020(5), 'President Cyril Ramaphosa: Additional Coronavirus COVID-19 economic and social relief measures', viewed 07 May 2020, from https:// www.gov.za/speeches/president-cyril-ramaphosa-additional-coronavirus-covid-19economic-and-social-relief.

Strachan, J.J., 2015, 'Narratives of difference and sameness', Verbum et Ecclesia 36(2), Art. \#1445, 1-8. https://doi.org/10.4102/ve.v36i2.1445
Thiselton, A.C., 2007, The hermeneutics of doctrine, William B. Eerdmans, Grand Rapids, MI.

Thiselton, A.C., 2015, Systematic theology, Eerdmans, Grand Rapids, MI.

Tralac, 2020, 'A new normal: UN lays out roadmap to lift economies and save jobs after COVID-19', viewed 07 May 2020, from https://www.tralac.org/news/article/14563a-new-normal-un-lays-out-roadmap-to-lift-economies-and-save-jobs-aftercovid-19.html.

Turner, V.R., 1969, The ritual process: Structure and anti-structure, Routledge \& Kegan Paul, London.

Turner, V.R., 1995, The ritual process: Structure and anti-structure, De Gruyter, New York, NY.

Unicef, 2020, 'Statement by the United Nations Network on Migration', viewed 05 May 2020, from https://www.unicef.org/press-releases/covid-19-does-notdiscriminate-nor-should-our-response.

Vanderwell, H., 2017, Caring worship: Helping worship leaders provide pastoral care through the liturgy, Cascade Books, Eugene, OR.

Van Doremalen, N., Bushmaker, T. \& Morris, D.H., 2020, 'Aerosol and surface stability of SARS-CoV-2 as compared with SARS-CoV-1' [Letter to the Editor], The New England Journal of Medicine 382(16). https://www.nejm.org/doi/full/10.1056/NE JMc2004973?query=RP\&cookieSet=1

Van Gennep, A., 1909, Les rites de passage, Emile Nourry, Paris.

Van Gennep, A., 1960, The rites of passage, Routledge \& Kegan Paul, London.

Van Wyk, T., 2014, 'Church as heterotopia: Original research', HTS: Theological Studies 70(1), 1-7. https://doi.org/10.4102/hts.v70i1.2684

Van Wyk, T., 2019, 'Redressing the past, doing justice in the present: Necessary paradoxes', HTS Teologiese Studies/Theological Studies 75(4), a5625. https://doi. paradoxes', HTS Teologiese Stuc
org/10.4102/hts.v75i4.5625

Volf, M., 1996, Exclusion and embrace: A theological exploration of identity, otherness, and reconciliation, Abingdon Press, Nashville, TN.

Wepener, C., 2014, Van voor die wieg tot na die graf, Bybelkor, Wellington.

Wepener, C.J., 2015, “"Bliksem!”/Damn it! A ritual-liturgical appreciation of a deadly sin for an angry nation', Verbum et Ecclesia 36(3), Art. \#1422, 1-8. https://doi. org/10.4102/ve.v36i3.1422

Williams, M., 2020, "The "new normal": SA likely heading for "partial lockdown", says Winde', News24, viewed 07 May 2020, from https://www.news24.com/SouthAfrica/ News/the-new-normal-sa-likely-heading-for-partial-lockdown-says-winde-20200420.

World Health Organisation, 2020, 'Coronavirus disease (COVID-19) advice for the public', viewed 11 May 2020, from https://www.who.int/emergencies/diseases/ novel-coronavirus-2019/advice-for-public.

Zizioulas, J. \& McPartlan, P., 2007, Communion and otherness: Further studies in personhood and the church, T\&T Clark, London.

Zizioulas, J.D., 2006, Communion and otherness: Further studies in personhood and the church, T\&T Clark, London. 